\title{
Power conversion of organic resources for reproduction of fertility and production of biofuel
}

\author{
S. Bulyghin, \\ Academician of the NAAS, Doctor of Agricultural Sciences, National Academy of Agrarian \\ Sciences of Ukraine \\ O. Demidenko, \\ doctor of agricultural Sciences Cherkasy state the agricultural research station NSC "Institute of \\ agriculture NAAS of Ukraine" \\ V. Velichko, \\ doctor of agricultural Sciences \\ NSC "Institute of soil science and agricultural chemistry named after A. N. Sokolovsky" of NAAS \\ of Ukraine"
}

The purpose. To determine theoretically possible volumes of vegetable biomass which can be used for power conversion. To justify inexpediency of use of a part of collateral products of plant growing for power purposes because of lowering fertility of lands of agricultural assignment of agrarian and industrial complex of Cherkassy oblast. Methods. Field and laboratory experiments, agrochemical diagnostics study, comparative- and-analytical method. Results. At exception of collateral products for power purposes (straw of cereal and leguminous crops, soya bean and rape), that makes about $20 \%$ of the common yield of collateral products, balance of organic substance of humus attains deficiency of the level $-0,19 \mathrm{t} / \mathrm{hectare}$, that is in 190 times deficient. Thus deficiency of nutrients increases for $125 \%$. Conclusions. Increase of deficiency of humus and nutrients at exception of collateral products for power needs causes inexpediency of utilization of collateral products for that purpose because of lowering fertility of lands of agricultural assignment.

Key words: balance of humus, collateral products, biofuel, humus, nutrient elements.

In modern farming conditions in the agroindustrial complex of the Cherkasy region, the most suitable model of farming is the scientifically biologized model with a closed production cycle, with an optimized structure of crop area and a balanced ratio of branches of livestock and plant growing in the immediate and long-term perspective. The agricultural biology of the Cherkassy region is an innovative technological basis for the revival of agricultural production, which allows in the near future to bring the region to a new technological level and make the crop production competitive on the domestic and foreign markets $[1,2,3]$. Until recently, it was considered that the source of anthropogenic carbon dioxide inflow into the atmosphere is energy, which should include modern boilers for straw, transport and industry, where a significant amount of $\mathrm{CO} 2$ is emitted during combustion of organic fuels. According to the level of carbon dioxide entering the atmosphere, agriculture is not inferior to industry, because its share accounts for $25 \%$ of greenhouse gas emissions due to humus costs $[4,5]$. Hence the solution to the problem of increasing the accumulation of humus in the soil can contribute to solving the problem of global warming [7]. The main task of cultivating the soil is minimization of its depth and number of passages in the field of soil machinery, and the use of straw as organic fertilizer and energy in soil cultivation in agrocentoses of crop rotation is, from an economic and ecological point of view, an actual and strategic direction of development of the agrarian sector of the Cherkasy region and Ukraine as a whole [6-8].

The use of biofuels requires careful balancing in terms of food and energy needs. Therefore, the spread of the use of biological energy resources is impossible without a thorough justification of the parameters of its technical and technological support. At the same time, in the process of conversion of organic raw materials into biofuels, it is necessary to harmonize technical, technological, economic, environmental and social indicators. Each measure proposed for implementation in agroecosystems should be aimed at 
maintaining the soil fertility, and, if possible, contribute to the enhanced reproduction of soil fertility. This has a direct bearing on the production and use of biofuels. In this regard, a serious scientific problem is the determination of the volumes of plant biomass that can be used for thermal needs without detriment to the reproduction of soil fertility in the agroindustrial complex of Cherkasy region.

Determination of the volumes of straw and stems of field crops for heat needs also requires the availability of valid values of the output of dry biomass of field crops. If there is a reasonable value of this indicator, it would be possible to objectively determine the annual volume of straw and stems of field crops for heat needs. Therefore, a serious problem is the determination of the volumes of plant biomass, which can be used for thermal needs, without prejudice to the reproduction of soil fertility. The level of assessment of volumetric plant biomass for heat requirements according to existing methods can vary from 30 to $100 \%$ of the total. After determining the amount of available biomass, it is necessary to develop the directions of its rational use for energy needs, and to determine the structural and technological parameters of equipment for the conversion of raw materials of vegetable origin [11-12].

The aim of the study. To establish theoretically possible volumes of plant biomass that can be used for energy conversion and to substantiate the inexpediency of using part of the by-product of crop production for energy purposes in connection with the declining state of fertility of agricultural land of the agrarian and industrial complex of Cherkasy region.

Materials and methods of research. The researches were carried out in the conditions of the central part of the left-bank forest-steppe of Ukraine in the long-term (more than 36 years) stationary experiment of the Drabiv experimental field of the Cherkasy State Research Station NSC "Institute of Agriculture of NAAS". The territory of the experimental field is located on the third terrace of the Dnieper in the Nosov-Kremenchug agro-soil region, and for a more detailed classification of VS Samburova - in the Drabiv agro-soil region, the relief of which is plain, weakly wavy, with small ravines. The agrarian region occupies the southern part of the ancient terraces of the Middle Dnieper, including the left-bank areas of Cherkasy and terrains of the Poltava region.

The agrochemical characteristics and soil fertility status of Cherkasy oblast for 2009-2015 were conducted by the Cherkasy branch of the State Institution of Soil Protection Institute of Ukraine. Balance calculations of organic matter of humus and nutrients in the agroindustrial complex of Cherkasy region and experiments conducted according to the generally accepted methodology of the NSC Institute of Soil Science and Agrochemistry. O.N. Sokolovsky The coefficients of mineralization of the goose were determined by removing nitrogen from the soil by the main crop production.

The output of straw and stems for heat needs is defined as the difference between the amount of grain and legume crop biomass and legumes and rape stems and soybeans (with the exception of stems of maize for grain and sunflower, the plant biomass of which in most cases remains in the field in full), and losses in harvesting and stubble, as well as the cost of straw for animal feeding and litter by the method SM Kukharetz, G. A.Golub [12].

Research results. Significant achievements of the agroindustrial complex of Cherkasy region over the past 6 years are high yields: winter wheat is 4.69-4.72 $\mathrm{t} /$ ha, maize for corn - 5.33-7.13 tons / ha, sugar beet - 32.7- 34,3,6 t / ha, rape $-2,23-2,96 \mathrm{t} / \mathrm{ha}$. Measures that achieve high yields of agricultural crops are as follows:

- when cultivating grain crops on an area of over 350 thousand hectares, technologies of biological farming with mulching of the soil surface are carried out by post-dormancy residues and byproducts of crop production under cereals, and, in many cases, under cultivated crops (soybeans, rape, sunflower, corn);

- the reproduction of the fertility of the land occurs due to the use of the unproductive part of the crop (straw of grain and leguminous plants, crushed sunflower stems, corn, sorghum, husk, rough, etc.). The norm of introducing organic fertilizers of vegetable origin, calculated on semiperforated manure, is brought to $7 \mathrm{t} / \mathrm{ha}$, and in the long run - at least $15-18 \mathrm{t} / \mathrm{ha}$;

Mineral fertilizers are used in production in an approximately optimal ratio from the amount of unprocessed crop left on the fields, which is the basis of biological technologies for growing crop production; 
- optimization of the structure of sown areas in accordance with the norms of the optimal ratio of crops in crop rotation for the forest-steppe zone;

- the proportion of biological nitrogen increased due to the increase in the area of legumes from $2-3 \%$ to $4-5 \%$ in the near future and the area of sederate crops to $20-25$ thousand hectares, which is equivalent to $30-40 \mathrm{t} /$ ha of manure;

- in the structure of the crop area of the area, the sowing of winter crops by good and best predecessors is more than 220 thousand hectares, and the area of annual and perennial grasses is about 45 thousand hectares.

- protection of crops from weeds is carried out by agrotechnical measures (cultivation and semi-couples) in a complex with herbicides, and protection of crops from pests and diseases is increasingly carried out by preventive and biological methods;

The provision of biological farming technologies is based on the use of wide-reaching heavy disk harrows, important combine cultivators, roller mills and grain-seeded drills, or direct seeding seeders.

Over the past 5 years, in the agroindustrial complex, about $7.0 \mathrm{t} /$ ha of organic mass of by-products per hectare. The content of nutrients from by-products is $130-140 \mathrm{~kg} /$ ha of nitrogen, phosphorus and potassium. The first thing that depends on commodity producers in the region is the return to optimization of crop rotation, which is the backbone of the agricultural system. In Cherkassy region, during the last 20 years, the structure of crop rotation has undergone a significant transformation, which entails both negative and positive effects. Thus, compared with 1990, in 2015, the percentage of grain crops has grown to $60 \%$ or 1.3 times, including barley -2.7 and corn -1.7 times. There was a tendency to increase the area of wheat cropping.

The structure of the crop area of technical crops has fundamentally changed: the percentage of areas in 20102015 has increased 1.7 times and has undergone significant changes in the composition of crops. The share of sugar beets has decreased by almost 4 times; sunflower grew 3.5 times, rape -7 times; soybeans - 5 times. In connection with the reduction of livestock in the region, the percentage of fodder crops has decreased by 3 times. Correspondingly, corn sown areas of silage, perennial and perennial grasses declined 2.7-3 times. It is a great concern to reduce the area of crops of peas: in the structure of crops, peas make up $1.7 \%$ versus $5-6 \%$ in 1990 . The agroecological state of the soil cover of the region was adversely affected by the reduction of the applied organic fertilizers: from 10.6 tons / ha in 1990 to less than 1 ton / ha in 2010-2015. The main problem in today's agroeconomic conditions in the Cherkasy region is the problem of ensuring a deficit organic balance fertilizers in conditions of animal husbandry curtailment. Taking into account the amount of produced organic fertilizers of vegetable origin, we have a stable excess of the norm of access to the deficit-free humus balance in the range of 1.5-2.5 times for the conditions of the Central Forest-steppe of Ukraine.

Taking into account the by-products of crop production: poppy, pericarp and root remains, in 2010-2015, each hectare accounted for 7.5 hectares of organic vegetable mass of by-products. At the root remains in the structure of the non-market share of the crop accounted for $40-45 \%$, which is important for stabilizing the productivity of agriculture and reproduction of fertility in modern conditions of farming. Over the past 20 years, each hectare of arable land has gained 120 tons of organic matter, of which 51 tons or about 43 per cent of the root remains.

1. Output and accumulation of by-products and crop rotation in the agroindustrial complex of Cherkasy region for $1990-2015$.

\begin{tabular}{|l|l|l|l|}
\hline \multirow{2}{*}{ Indexes } & Years & $\mathbf{2 0 1 2 - 2 0 1 5}$ \\
\cline { 2 - 4 } & $\mathbf{1 9 9 0}$ & $\mathbf{2 0 0 0}$ & $\mathbf{2 0}$ \\
\hline Total Organic Mass, t / ha & 7,1 & 5,8 & 7,5 \\
\hline Total root mass, t / ha & 2,8 & 2,1 & 3,0 \\
\hline Increasing yield of organic mass, t / ha & 7,1 & 55 & 120 \\
\hline Growing yield of root, mass. t / ha & 2,8 & 25 & 51 \\
\hline Total Organic Mass, million tons & 7,7 & 5,9 & 8,0 \\
\hline Total Root Mass, million tons & 3,0 & 2,9 & 3,2 \\
\hline Growing yield of organic mass, million tons & 7,7 & 66 & 120 \\
\hline Growing yield of root mass, mn. tons & 3,0 & 27 & 56 \\
\hline
\end{tabular}


Taking into account the list of main crops that are part of the modern structure of the crop area of the region, the increasing yield of organic mass of the non-market share of the harvest for two decades amounted to 120 million tons, and the root - 56 million tons (44\%) (Table 1). According to the indicated indicators, the region reached the level of 1990 , when $95 \%$ of the by-products were withdrawn for livestock production and more than $10 \mathrm{t} /$ ha of manure was introduced. In today's conditions of farming, it is the byproduct of crop production that stabilizes the productivity and fertility of agricultural land. The amount of organic organic matter, calculated on the semi-perforated manure with the introduction of nitrogen compensation, is equivalent to 15-18 tons of manure per hectare of arable land on the scale of the region, and the nutrient element content in it is not less than $130 \mathrm{~kg} /$ ha of nitrogen, phosphorus and potassium per 1 hectare.

The West for economically significant improvement of acidic soils is their liming. Each ton of lime fertilizer gives on acidic and strongly acid soils, during its entire lifetime (about 10 years), about 1.0 tons of additional crop yields per grain. The main value of lime for soil fertility is that it is a source of absorbed calcium, which prevents losses of the most valuable part of the soil - humus, so it is, so to speak, the guardian of its fertility. However, without State support of liming in the region is not carried out.

It should not be forgotten that in the straw of grain crops contains $0.25-0.31 \%$ of calcium; in corn stalks about $0.5 \%$, in straw peas -1.82 , in sunflower stems -1.53 , in buckwheat straw -0.95 , in soybeans $-1.4 \%$, in fodder crops $-0.95-2.53 \%$. The removal of the main products of calcium from the soil is much less than the accumulation of by-products: cereals 3-5 times, corn - 16 times, sunflower - 8 times, peas and soybeans - 9-20 times.

\section{Receipt of plant calcium and change of soils with acid reaction in agroindustrial complex of Cherkasy region for $1990-2015$.}

\begin{tabular}{|c|c|c|c|c|}
\hline \multirow{2}{*}{ ndexes } & \multicolumn{4}{|c|}{ Years } \\
\hline & 1990 & 2000 & 2010 & 2015 \\
\hline Revenue of $\mathrm{CaCO}$ by years, $\mathrm{kg} / \mathrm{ha}(\mathrm{dp})^{*}$. & 5 & 62 & 71 & 80 \\
\hline Total inflow of $\mathrm{CaCO}_{3}, \mathrm{~kg} / \mathrm{ha}(\mathrm{dp})$ & 5 & 94 & 236 & 610 \\
\hline Total inflow of $\mathrm{CaCO}_{3}, \mathrm{~kg} / \mathrm{ha}(\mathrm{fpm})^{* *}$ & 9 & 168 & 420 & 1085 \\
\hline Revenue of $\mathrm{CaCO}$ by years, ths. Tons (dp) & 10 & 65 & 77 & 87 \\
\hline Total inflow of $\mathrm{CaCO}_{3}$, ths tons (dp) & 10 & 112 & 265 & 665 \\
\hline Total inflow of $\mathrm{CaCO}_{3}$, ths. Tons (fpm) & 18 & 200 & 470 & 1185 \\
\hline *** area of acid soils, $\%$ & 19 & 29 & 33 & 23 \\
\hline *** area of acid soils, thousand hectares & 225 & 288 & 310 & 208 \\
\hline
\end{tabular}

${ }^{*}$ d. $p$ - an active substance

${ }^{* *}$ f. $\mathrm{m}$ - physical mass

*** according to the data of the State Farm Crop Protection Agency as of 2015

With the abandonment of by-products of plant growing at the place of cultivation in the area of the region, about 80 thousand tons of active form of calcium is returned (on average, 1 larch is about $45 \mathrm{~kg}$ ). In the case of by-products produced in the agro-industrial complex of the region in $2010-2015,80 \mathrm{~kg} / \mathrm{ha}$ SaSO3 is introduced per year per year. The total income was $610 \mathrm{~kg} / \mathrm{ha}$, and in physical weight - $1085 \mathrm{~kg} / \mathrm{ha}$.

Total in the region for 20 years with by-products made 87 thousand tons of $\mathrm{d}$. P. CaCO3. The total inflow of SaSO3 over 20 years amounted to 665 thousand tons, and in physical mass - 1,185 thousand tons. For comparison: in 1990, when 12509 thousand tons of manure were introduced, 112 thousand tons of $\mathrm{CaCO} 3$ in $\mathrm{ft}$ were returned to the soil. $\mathrm{m}$, and in 2015 - almost 100 thousand tons without the cost of export and import.

According to official data of the Cherkassy branch of the state corporation "State Crop Protection" in the region from 1990 to 2005 there was an increase in the area of acid soils in 1.38 times, and the percentage of the area - 1.74 times. Since 2006, the areas with acid soils have stabilized, and in 2010 they have fallen to the 1990 level. It can be assumed that the calcium intake from the unproduct share of the crop as of 2005 is 
critical or minimal enough to stop decalcification and the beginning of deoxidation of soils of chernozem type agricultural use due to biogenic melioration, namely straw and by-products of other crops.

To date, according to the surveys, the area of acid soils in the region is about 208 thousand hectares. Compared with 2005, the reduction of the area of acid soils was about $33 \%$. With the help of a non-market share (by-products, slurry, pericarp and root residuals), it is possible to return the active form of calcium to the soil and provide annual biogenic calcium (calcium recirculation) in each field with a significant reduction in the cost of liming the soil and the most cultivated products in agrocentoses in crop rotation.

In the production conditions, the natural order of supply of active form of plant calcium to the soil is provided, which allows to lower the active and potential acidity, saturate the soil calcium complex and create a positive balance in the soil. Particularly enhanced efficiency of nutrient liming of soils due to the application of the latest technology of soil cultivation, which ensure the surface wrapping of the unproductive part of the crop in the soil.

In 5-way crop rotations with saturation of $60 \%$ of grain, including $20 \%$ - high, $40 \%$ - corn and in crop rotation, where part of corn (20\%) and peas are replaced by herbs and barley $(20 \%)$, the use of by-products in the fieldless field cultivation contributes to the formation of a positive balance of organic matter that corresponds to the increased reproduction of chernozem fertility, whereas in the systematic plowing, to a greater extent, the surface cultivation, in the smaller, forms the balance of organic matter, which corresponds to a simple (in crop rotation with peas) and an expanded reproduction of fertility in crop rotation with perennial herbs.

Short-breeding 5-crop rotations more effectively contribute to the formation of a deficit-free balance of organic matter than in 10-grain grain-seed crop rotation, both when introduced into manure, and when replaced by the equivalent of by-products. It was established that with the maintenance of 10-grain graingrowing crop rotation with saturated cereals $50 \%$, peas $-10 \%$, sugar beet $-20 \%$, fodder crops $-40 \%$ without mineral feeding at the expense of by-products in the amount of $5 \mathrm{t} /$ productivity at $0.62 \mathrm{t} /$ ha with. A., and the economic output increases by $0.67 \mathrm{t} / \mathrm{ha}$. oh, or by $117 \%$ and $115 \%$. The replacement of $6 \mathrm{t} / \mathrm{ha}$ of manure against the background of mineral nutrition by by-products is $7 \mathrm{t} / \mathrm{ha}$, with a $145 \mathrm{~kg} \mathrm{pp}$ of NPK contributing to an increase in output from. at. at $1.37 \mathrm{t} / \mathrm{ha}$, and economic output - by $1.47 \mathrm{t} / \mathrm{ha}$, or by $120 \%$ and $125 \%$. Growth of crop rotation productivity after leaving. at. from 1 hectare in the period of 2001-2010, when on the field all the by-products were left in the field in the amount of $7 \mathrm{t} /$ ha against the background of mineral nutrition ( $145 \mathrm{~kg}$ of rice NPK) is provided by high productivity of new varieties and hybrids of corn, sugar beet and peas .

The comparative productivity of 10-way crop rotation with different types of organic fertilizers shows that in modern crop rotation without the use of manure the yield of grain units increased by $1.37 \mathrm{t} / \mathrm{ha}$, and the economic yield of grain units amounted to $5.99 \mathrm{t} /$ ha of manure using the use of by-products $-7.46 \mathrm{t} / \mathrm{ha}$. The productivity growth of a 10 -way crop rotation with a $50 \%$ grain saturation, $20 \%$ propagation and $40 \%$ of fodder crops, in modern conditions, takes place against the backdrop of declining soil fertility. By-product of plant growing gets more effective results when used together with manure.

For the agroindustrial complex of the Cherkasy region, the problem of gradualization of the territory is relevant. The reason - it's reared $91 \%$. the soil of agricultural land of agrarian enterprises of the region. The problem in the region's agriculture is a sharp decrease of 7-10 times the organic fertilizers, and 2.7-3 times of mineral fertilizers! As a result, the humus content in the soil of the region for the past 20 years has decreased by $0.25 \%$. Agrarians who admit this have no future.

In recent years, more and more is fueled by the idea that, in difficult economic conditions, the use in the energy balance of the country, the fuel obtained on the basis of organic raw materials of agrarian origin, firstly, reduces the total energy consumption in agricultural production, and secondly, increases the volume of regenerative energy sources, and thirdly, contributes to a more rational use of the remains of straw and stems of main crops, whose annual accumulation is 15-20 million tons. Rational use of biomass for energy purposes up to volyt reduce emissions of carbon dioxide, sulfur and nitrogen oxides into the atmosphere and restore the fertile layer of soil. Such a "policy" and Cherkasy oblast have not passed. Through the mass media, the idea of the feasibility of the use of by-products of crop production and energy problems is being formed. 
It is erroneous that consumption of straw in the form of biofuels can halt global climate change and solve energy problems, while straw burning can be neutral in terms of increasing the greenhouse effect (calorific value of straw of cereals $-10 * 103 \mathrm{MJ} / \mathrm{t}$, sunflower stems and corn $-12.5 * 103 \mathrm{MJ} / \mathrm{t}$ ). The conversion of by-products to $\mathrm{CO} 2$ and water in the presence of oxygen is not necessary for Ukrainians, and the enrichment of the soil with newly formed humus and its transformation into stable humus substances, which will ensure the reproduction of the Chernozem forest-steppe zone and ensure the National Security of Ukraine.

Maintaining a positive balance of humus and nutrients in soils is a determining factor in the removal of crop production for energy needs. At the same time, the quantity of by-products that can be used for heat needs is inversely proportional to the humus deficit in crop rotation soils. Thus, an increase in the humus deficit by $10 \mathrm{~kg} /$ ha causes the need to reduce the use of by-products to energy needs by up to $5 \%$. Therefore, it is necessary to clearly define the accepted values of the indicators for the calculation or the method for determining the balance of humus to obtain adequate conclusions about the possibility of using straw for heat needs [9-11].

3. Dynamics of fertility indices in agroindustrial complex of Cherkasy region for various economic purposes for 2010-2015.

\begin{tabular}{|c|c|c|c|c|c|c|c|}
\hline \multirow{2}{*}{ Indicators } & \multicolumn{6}{|l|}{ Years } & \multirow{2}{*}{$\begin{array}{l}2010- \\
2015\end{array}$} \\
\hline & 2010 & 2011 & 2012 & 2013 & 2014 & 2015 & \\
\hline \multicolumn{8}{|c|}{ Indicators for the removal of by-products for business purposes (30\%) } \\
\hline $\begin{array}{l}\text { Entrance } \\
\text { sideways } \\
\text { products, } \\
\text { million tons }\end{array}$ & 5,1 & 4,6 & 7,0 & 6,6 & 7,2 & 6,0 & 6,1 \\
\hline \multicolumn{8}{|l|}{ Balance: } \\
\hline $\begin{array}{l}\text { organic } \\
\text { substances } \\
\text { humus, t / ha }\end{array}$ & $-0,41$ & $-0,42$ & $+0,01$ & $+0,02$ & $-0,076$ & $-0,035$ & $-0,001$ \\
\hline $\begin{array}{l}\text { nutritious } \\
\text { substances } \\
\text { (NPK), kg / ha }\end{array}$ & -178 & -118 & -194 & $-25,0$ & $-45,0$ & $-42,0$ & -100 \\
\hline \multicolumn{8}{|c|}{ Indicators for the removal of by-products for energy purposes (50\%) } \\
\hline $\begin{array}{l}\text { Withdrawal } \\
\text { sideways } \\
\text { products } \\
\text { for energy } \\
\text { purposes, } \\
\text { million tons }\end{array}$ & 1,05 & 0,95 & 1,50 & 1,35 & 1,45 & 1,20 & 1,25 \\
\hline \multicolumn{8}{|l|}{ Balance: } \\
\hline $\begin{array}{l}\text { organic } \\
\text { substances } \\
\text { humus, t / ha }\end{array}$ & $-0,48$ & $-0,55$ & $+0,007$ & $+0,016$ & $-0,09$ & $-0,041$ & $-0,19$ \\
\hline $\begin{array}{l}\text { nutritious } \\
\text { substances } \\
(\mathrm{NPK}), \mathrm{kg} / \mathrm{ha}\end{array}$ & -215 & -145 & -235 & $-30,0$ & $-55,0$ & $-50,0$ & -125 \\
\hline
\end{tabular}

According to indicators characterizing agricultural production in recent years, the limit volumes of plant biomass (straw), which can be used for heat needs, are calculated. It should be noted that for a general 
deficit of humus in excess of $75 \mathrm{~kg} / \mathrm{ha}$, the use of straw for heat needs is impossible due to non-compliance with the condition of a positive balance of humus. The maximum amount of straw that can be used for thermal needs, for a zero balance of humus, is about $40 \%$. According to the calculations in the agroindustrial complex of the Cherkasy region, the humus balance, calculated on the removal of nitrogen by crops, is reduced by the limit values (less than $75 \mathrm{~kg} / \mathrm{ha}$ ), and in certain areas it is reduced to negative values, which limits the use of by-products to heat resources.

Thus, the balance of organic matter of humus was: in $2009-0.40 \mathrm{t} / \mathrm{ha}$, in $2010-0.42 \mathrm{t} / \mathrm{ha}$, in $2012-+$ $0.01 \mathrm{t} / \mathrm{ha}$, in $2013-0.02 \mathrm{t} / \mathrm{ha}$, in $2014-0,076$ tons / ha, in $2015-0,035$ tons / ha. The average balance of organic matter of humus was at the level of simple reproduction, and the balance of nutrients was scarce at the level of $-100 \mathrm{~kg} / \mathrm{ha}$ NPK. In the case of removal of by-products for energy purposes (straw of cereals, legumes, soybeans and rape), which accounts for about $20 \%$ of the total output of by-products, the balance of organic matter of humus reaches a deficit of $-0.19 \mathrm{t} / \mathrm{ha}$, which is shorter 190 times. In this case, the shortage of batteries increases by $125 \%$ (Table 3 ).

\section{Conclusions}

Biomass of by-products in agriculture, as "the derivative of the energy of the Sun in chemical form, is not only one of the most popular and most versatile resources of the earth," but also the basis of environmental sustainability of agro-landscapes through the formation of a positive balance of organic matter humus and a means of providing people with food. You should not allow biomass by-products to smoke through a pipe because "the big crime is burning straw on the fields, but even more a crime is the burning of straw in modern boilers to solve energy problems."

When removing by-products for energy purposes (straw of cereals, legumes, soybeans and rape), which is about $20 \%$ of the total output of by-products, the balance of organic matter of humus reaches a deficit of $0.19 \mathrm{t} / \mathrm{ha}$, which is shorter 190 times. In this case, the deficiency of the batteries increases by $125 \%$.

Maintaining the balance of humus in the soils of the agroindustrial complex of Cherkasy region is a determining factor in the use of by-products of crop production for energy needs. At the same time, the quantity of by-products that can be used for heat needs is inversely proportional to the humus deficit in crop rotation soils. The growth of the humus deficit in removing by-products to energy problems necessitates the elimination of the use of by-products for energy needs due to declining fertility of agricultural land.

\section{References}

1. Demidenko O. V. Regulation of the use of organic resources of the AIC of Cherkasy region for reproduction of fertility and production of biofuels / [Demidenko M.I. Blaschuk, Yu.I. Krivda, O.M. Gorbachech] // The guidebook of the Ukrainian farmer. - 2016. - Volume 1. - P. 170-173.

2. Demidenko O.V. To balance the structure of crop rotation with fertility of chernozems in the zone of the central forest-steppe of Ukraine is quite real / O. V. Demidenko // Grain and bread. - 2015. - № 1. - P. 54-56.

3. Demidenko O. V. Humus state of Chernozem Chernozem region and ways of reproduction of their fertility / O. V. Demidenko // Scientific collection Soil protection. - sunset And look. - State institution "Institute of protection soils ". - Kiev - 2014. - pp. 240-243.

4. The newest technologies of bioconversion: Monograph / Ya.B. Blum gg Geletukha, IP Grigoryuk, VO Dubrovin, Al Yemets, GM Zabarny, GM Kaletnik and others. - K .: Agrar Media Group, 2010.- 326 p.

5. Kaletnik G.M. Development of Biofuels Market in Ukraine: Monograph / G.M. Kaletnik - K .: Agrar. science, 2008. - 464 pp.

6. Saiko V.F. Use of fertilizer for crop production in Ukraine / V.F. Saiko // Between. those national team "Agriculture". - wines.81. - К.: ВД "ЭКМО". - 2009. - p.3-10.

7. Saiko V.F. Agriculture in the context of climate change / VF Saiko // Selected scientific parks. K .: Agrarian Science. - 2011. - p.312-326.

8. Crop rotations in agriculture of Ukraine / edited by VF Saika, P.I. Boyka - K .: Agrarian Science, 2002. $147 \mathrm{pp}$.

9. Golub G.A. Problems of using straw as fuel / G. A.Golub // Bulletin of agrarian science. - 2010. - No. 8. - P. 49-52. 
10. Golub G.A. Scientific, Technical and Economic Problems of the Production and Use of Biofuels in Agroecosystems / G.A.Golub // Visnyk of Sumy National Agrarian University. Series "Mechanization and automation of production processes." - Issue 1 (21). - Sumy: SNAU, 2010. -172 p. - S.72-80.

11. Kukharets S.M. Autonomy of Agroecosystems Based on Biological Fuels / Kukharets SM // Sb. sciences A special issue for the VII scientific-practical conference "Modern problems of balanced use of nature". -Kamenyets-Podilsky: PDATU, 2012. - P. 149-154.

12. Kukharets S.M. Regulation of the use of organic resources for the production of biofuels / SM Kukharet, G. A.Golub // Zbr. sciences works Agricultural machines. - in. 24th - 2013 - p.187-194. 